\title{
CORRIGENDA
}

\section{WILLIAM CHESELDEN (1688-1752)}

IT has just come to our notice that in Kirby's "Surgery of Cataract" (J. B. Lippincott Co., Philadelphia, 1950), p. 22, one of the greatest pioneers of English surgery is described as a "well-known charlatan". Cheselden was certainly well-known, not only to the staff of St. Thomas's Hospital, but throughout the world, and today his portrait occupies an honoured place among the great in the Royal College of Surgeons in England. Not only was he the first to practise the operation of iridotomy but his contributions to general surgery were immense and classical.

\section{CORNEAL NERVE FIBRES}

DRS ZANDER and WEDDELL regret that their paper "The Reaction of Corneal Nerve Fibres to Injury" (Brit. J. Ophthal., 35, 61) appears to suggest that Dr. F. C. Rodger had stated in his paper "The Pattern of the Corneal Innervation in Rabbits" (Brit. J. Ophthal., 34, 112) that the cornea contained sympathetic nerve fibres. Dr. Rodger described two anatomically distinct types of fibre in the rabbit cornea, and remarked on the interesting similarity of one of them to nerve fibres seen in the vicinity of blood vessels in the skin and iris, but he did not conclude that these fibres were sympathetic in origin.

\section{BOOK REVIEW}

Genetics in Ophthalmology. By ARnOLd SorsBy. 1951. Butterworth, London. Pp. 251, 233 figs (10 col.) (42s.).

In the preface the author places ophthalmological genetics in perspective by ndicating that infective diseases have been replaced by cataract, glaucoma, myopia, senile macular degeneration, and a group of congenital, hereditary, and developmental defects as the main causes of blindness. None of these is explicable in terms of bacteriology and all may have a genetic basis. It has become apparent that, in medicine, the constitutional factor, as opposed to the extraneous factor, of disease has come to be the starting point for further advance.

The first section of the book proceeds from a description of the behaviour of the nucleus during division of the germ cell to build up, step by step, the theoretical knowledge which we have inherited from past workers on the modes of inheritance, the gene and chromosome types of inheritance (illustrated by human pedigrees), and clinical varieties of genetic disease. This section closes with a discussion on the prospects of the control of genetic disease, drawing from experiences with diabetes, $\mathrm{Rh}$ factor, acholuric jaundice, etc., a modest optimism. Experimental medical genetics is briefly touched upon, and sound advice is given regarding the responsibility of the physician in guiding patients about the possible transmission of their inherited defects. 
The second section describes isolated ocular anomalies; the globe as a whole, the cornea, lens, uveal tract, retina, optic nerve, and other tissues are taken in turn, and each is illustrated with pedigrees. A final section discusses generalized disorders with ocular aspects, under the headings of metabolic diseases, systemic disorders, and miscellaneous syndromes. A selected bibliography and index complete the volume.

This work is so written that no special knowledge of heredity is required to understand it. The fundamentals of the subject are discussed and illustrated before individual and problematical pedigrees are examined. On every page the enormous advances made in recent years and the widening field which the study of genetics embraces are evident, and are contrasted with the equally enormous defects in our detailed knowledge. The book is comprehensive, up-to-date, and well in line with the tradition of British ophthalmological genetics laid by Edward Nettleship and C. H. Usher. It is hopeful in its outlook for future research and the control of hereditary disease, and is informed by the deep sense of social responsibility which we have learned to expect from its author.

\section{OBITUARY}

\section{E. H. HARRIES-JONES}

If Evan Harries Harries-Jones had lived for one more day, he would have completed half-a-century's service as ophthalmic surgeon to the Northampton General Hospital; and a few more weeks of health would have enabled him to attend the 36th Oxford Ophthalmological Congress, at which he was greatly missed by his friends. Readers of this journal all over the world will remember him with affectionate gratitude, and their sympathy is extended to his widow and to his daughter, Mrs. S. H. G. Humfrey.

H.-J. stood out as a tower of strength amidst changes which have constituted a revolution in the social system as well as in the conduct of medical practice. Born at Rhyl in 1874, he entered medicine as an apprentice to Dr. Hughes of Ruthin at the age of 16, and later studied at Edinburgh and Dublin. He graduated M.B., C.M. in 1897, and was awarded the M.D. of Edinburgh University in 1900. A series of resident posts at the Birmingham Eye Hospital allowed H.-J. scope to develop the clinical judgment for which he became renowned beyond the confines of his county, and the Singlehurst Block, presented to the Northampton General Hosp tal in 1924 by a grateful patient, stands as an enduring reminder of his work.

Throughout his long professional life H.-J. found time for other activities, including the study of history. He was highly honoured by his fellow-ophthalmologists who chose him to be President of the Midland Ophthalmological Society, President of the South Midlands Branch of the B.M.A., and a Vice-President of the Ophthalmological Society of the United Kingdom. He was also a founder-member and counsellor of the Oxford Ophthalmological Congress, but these and the other distinctions which fell to his lot were transcended by H.-J's own splendid personality. In his company barriers of age and rank were swept aside, and his laugh resounded with human generosity. All his colleagues will treasure the memory of their association with Harries-Jones. 